\title{
Kathmandu Declaration on Cysticercosis : Towards Eradication
}

\author{
Basant Pant ${ }^{1}$, Sharad Onta ${ }^{2}$, Sushil Nath Pyakurel ${ }^{3}$, Biraj Man Karmacharya ${ }^{4}$, Bimal Kumar Nirmal ${ }^{5}$, \\ Ana Flisser ${ }^{6}$, Marshall Lightowlers ${ }^{7}$
}

\author{
${ }^{1}$ Department of Neurosurgery, Annapurna Neurological Institute \& Allied Sciences, Maitighar, Kathmandu, Nepal \\ ${ }^{2}$ Nepal Public Health Foundation, Kathmandu, Nepal \\ ${ }^{3}$ Ministry of Health \& Population, Kathmandu, Nepal \\ ${ }^{4}$ Department of Community Medicine, Kathmandu University, Dhulikhel, Kathmandu, Nepal \\ ${ }^{5}$ Department of Livestock Services, Kathmandu, Nepal \\ ${ }^{6}$ Department of Microbiology \& Parasitology, National Autonomous University of Mexico, Mexico \\ ${ }^{7}$ Department of Veterinary Science, The University of Melbourne, Australia
}

\section{CORRESPONDENCE}

Dr. Basant Pant

Depatment of Neurosurgery,

Annapurna Neurological Institute \& Allied

Sciences, Maitighar, Kathmandu

Email :neuronepal94@gmail.com

\section{ARTICLE INFO}

Article History

Submitted: 01 November, 2020

Accepted: 19 December, 2020

Published: 8 February, 2021

Source of support: None

Conflict of Interest: None

\begin{abstract}
In December 2018, an international conference on cysticercosis was held in Kathmandu,Nepal with the theme, "Towards Eradication". With the collaboration and participation of human-health and animal-health related organizations, the culmination of this event was the Kathmandu Declaration on cysticercosisrealizing an urgency to take action for its prevention and management.Of the 10 points mentioned in the declaration, all of the keynote speakers and participants on the conference endorsed the activities on commitment for eliminating cysticercosis, urgedthe government to internalize its primary responsibility and role in controlling cysticercosis, and called for the stakeholders for multisectoral collaboration. The authors believe that this declaration and further action definitely strive towards meeting the theme of the conference to eradicate cysticercosis with collaboration among multiple sectors. Several important strategies are also outlined in this article by expanding the statements on the declaration that must be implemented to achieve the targeted goal.
\end{abstract}

Keywords: Cysticercosis; Eradication; HCC; Conference

\section{INTRODUCTION}

Cysticercosis is a rear infectious disease caused by presence and accumulation of the larval cysts of Taenia Solium within tissues of body. Cysticercosis is prevalent worldwide entrenched in humans and pigs in developing countries and emerging as a major health problem. ${ }^{1}$ Taeniasolium is a neglected zoonotic parasite endemic to most underdeveloped countries and regions where pig raising and pork consumption are not restricted. ${ }^{2}$ Its life cycle involves humans as definitive and pigs as intermediate hosts, but its clinical importance is mainly related to the accidental intake of tapeworm eggs by humans and their development into cysticerci in the host's central nervous system - a condition called neurocysticercosis. ${ }^{3}$ Neurocysticercosis (NCC) is the most common parasitic disease of the central nervous system and is a major cause of epilepsy and neurological morbidity in humans in endemic areas of the world. ${ }^{4}$

The Himalayan Cysticercosis conference focusing on eradication of Cysticercosis, which took place in Kathmandu,Nepal in Dec 2018 was a milestone event bringing together National \& International stakeholders with focus area of cysticersosis. Delegates and key persons from Health Ministry, along with senior diplomats and government officials around the globe, Key researchers in Cysticercosis, officials of International organisations, hundreds of Neurologists, Neurosurgeons, Microbiologist, Veterinaryspecialists, Researchers and other health care workers along with journalists. With all the key stakeholders in the single event, $\mathrm{HCC}$ made it plain that together we can eliminate and eradicate cysticercosis with the presentations of key works of national and international delegates on cysticercosis. A declaration was made with a commitment of $7 \mathrm{National}$ and International key personals including Stakeholder from Health Ministry, Public Health, Microbiologists, Veterinary specialist.

The main aim of the commitment was to create a task force and collaborate together for eradication of cysticercosis. This 2 days Conference was a first ever conference organized in Nepal, recognizing the problem of cysticercosis in the country and its impact in population, identifying Neurocysticercosis as a highest cause of adult onset seizure and realizing an urgency to take action for its prevention and management. 
The organizers and participants of the HIMALAYAN CYSTICERCOSIS CONFERENCE believed in possibility to eradicate cysticercosis, and expressed commitment for

1. Formation of a special task force to plan on eradication of Cysticercosis on the basis of available evidences and learning from experiences of other countries.

2. Initiating necessary actions to take appropriate management of the case, based on the principle of equity and justice to those suffering from cysticercosis.

3. Engage in research to produce relevant evidences necessary for policy formulation, strategic planning and programme development..

4. Collaboration with all partners at the national and international levels.

Internalizing its primary responsibility and role in controlling cysticercosis, we urge the Government:

1. To include problem of cysticercosis in health policy, planning and programs, as an agenda of public health.

2. To list Cysticercosis as a public health problem under waterborne disease.

3. Allocate resources necessary for multiple actions at the community, regional and national levels.

4. To capacitate, guide, support and facilitate activities conducted by the non-state stakeholders.

Appreciating multi sector collaboration, as key to control and prevent cysticercosis, we call to all the stakeholders at all levels:

1. To collaborate and act together at the policy and programme levels for controlling cysticercosis

2. To share learning experiences among each other for enhancing capacity to take actions for controlling cysticercosis.

\section{REFERENCES}

1. DD Joshi. A New Tapeworm Taenia solium Asian Genotype Recorded First Time in Nepal Through DNA Multiplex PCR Method. Nepal J Hosp Adm Heal Res Counc. 4AD;1.

2. Mafojane NA, Appleton CC, Krecek RC, Michael LM, Willingham AL. The current status of neurocysticercosis in Eastern and Southern Africa. In: Acta Tropica. Elsevier; 2003. p. 25-33.

3. Devleesschauwer B, Aryal A, Joshi DD, Rijal S, Sherchand $\mathrm{JB}$, Praet $\mathrm{N}$, et al. Epidemiology of taenia solium in Nepal: Is it influenced by the social characteristics of the population and the presence of Taenia asiatica? Trop Med Int Heal [Internet]. 2012 Aug [cited 2021 Feb 2];17(8):1019-22. Available from: https://pubmed.ncbi. nlm.nih.gov/22643112/

4. Sehgal R, Goyal K, Mewara A. Neurocysticercosis: A disease of neglect. Trop Parasitol [Internet]. 2013 [cited 2021 Feb 2];3(2):106. Available from: /pmc/articles/ PMC3889086/?report=abstract 